Michael Keating, Paul Cairney and Eve Hepburn

\title{
Policy Convergence, Transfer and Learning in the UK under Devolution
}

\begin{abstract}
This paper explores the policy transfer and learning process within the UK since 1999, examining the conditions in which transfer takes place among central and devolved governments. We distinguish among concurrent policies, policy competition, coercive transfer and policy learning. Policy transfer can be more or less coercive and constrained, while policy learning is voluntary. Mechanisms for transfer include financial instruments, political parties, the civil service and policy communities. Transfer can take place from centre to periphery, from periphery to centre and across the periphery. There is also transfer at European and international levels. As it is England that has tended to break with older policies, notably on public service provision, the pressure has been to follow its lead, with the devolved administrations resisting or conforming. The UK government has paid much less attention to possible learning from the devolved territories and sometimes has sought to insulate England from debates there, especially where politically sensitive matters or large resources are at stake. Learning among the devolved territories is only now really beginning.
\end{abstract}

\section{The Devolution Settlement and Policy Divergence}

The constitutional settlement in the United Kingdom is distinct in various respects. One is its radical asymmetry, with a legislative parliament/assembly in Scotland and Northern Ireland, an Assembly in Wales, which only in 2011 acquired primary legislative powers, and no meso level at all in England. The result is that the UK government and parliament double up as the government and parliament of England. So policy transfer between England and the devolved territories can be conceptualized either as horizontal, among the nations, or vertical, between centre and periphery; in practice it is most useful to see it as a bit of both. The United Kingdom is not a federation, with two orders of government, each with its own powers and competences. In theory, Westminster retains the right to legislate for all parts of the state, and so to impose its policy line, but in practice it is limited by convention (including the formalized Sewel Convention) ${ }^{i}$ whereby it only legislates in devolved matters with the agreement of the competent assembly or parliament. On the administrative side, devolution is strongly entrenched, since Whitehall ministers cannot act or spend in the devolved territories except where the devolution statutes expressly allow them to. Some Whitehall departments are in effect English departments, while others contain a mix of England, England-and-Wales, Great Britain, and United Kingdom responsibilities, which can be confusing, but the allocation of responsibility for service delivery is generally clear. Responsibility for policy areas defined more broadly is less clear and there is a marked interdependence in newer areas like climate change. The restoration of a full-time Secretary of State with a high political profile in 2008 led to some competition within the sphere of economic development, where both governments can claim competence. In Northern Ireland, the situation is slightly different as Direct Rule from 197299 and 2002-7 led to Northern Ireland's machinery becoming entangled with that of Whitehall, though devolution has led to a clearer demarcation of bureaucratic structures and responsibilities (Carmichael and Osborne, 2003; Birrell, 2010).

A final feature is that political devolution builds upon a history of administrative devolution and, in the case of Northern Ireland, a fifty-year interlude of legislative devolution, which has left a legacy of administrative differentiation, distinct policy styles and, in some fields, policy communities, if not of radical differences in public policy. The pre-devolution arrangements provided for some innovations at the periphery and some learning through Cabinet committees, working groups and civil service networks. 
Devolution left some of this intact. There is still a single British civil service, although Northern Ireland has had its own one since partition in 1921. The Northern Ireland Civil Service (NICS) has been characterised by 'parity and particularity' whereby administrative arrangements have diverged from London, but have remained within the ambit of a 'British way of doing things' (Carmichael, 2002). Direct rule encouraged greater integration with Whitehall machinery and a natural tendency to look to London for policy initiatives (Hayes, 1995). Elsewhere in the UK, the British civil service has been a mechanism for policy exchange as officials from the devolved and state governments have followed each others' work and drawn lessons. Fears were expressed that devolution might mean an end to the regular exchange of civil servants between the two levels but this appears largely unfounded, if only because there was not a lot of movement before devolution (Keating and Cairney, 2006). There was, however, a fall in working contacts and the acquaintances and networks that arose from regular travel to London have atrophied. The change of government in Scotland in 2007 did not lead to the rupture that some had predicted and relations with ministers and civil servants continued in the traditional mode, but there is less willingness to share papers and ideas that might be exploited by a competing political party (Cairney, 2011: 105). Ministerial committees preparing policy and legislation no longer include Scottish, Welsh and Northern Ireland ministers. At the same time, the Scottish Government has sought to strengthen its own policy capacity, a trend that had already started before 2007. Similarly, the Welsh Assembly Government sought to increase its central capacity by: (a) initiating a 'bonfire of the quangos' that led, in part, to the assimilation of staff from large public bodies (such as the Welsh Development Agency); and, (b) encouraging a broader Welsh public service from which to recruit (Cairney, 2009a). In Northern Ireland a decision was made to review the system of public administration inherited from direct rule arrangements in 2000, with a view to improve the delivery of public services (Birrell, 2008). After a wide consultation process, the Review of Public Administration (RPA) recommended a modernisation of public services in NI, including a restructuring of government agencies, a reduction in quangos, and an amalgamation of councils so that their number was reduced from 26 to 11. However, the implementation of the RPA stalled due to disagreement within the NI Executive on issues such as local government boundaries and the financing of the Reform programme. As a result, the 2011 Local Government elections proceeded on the basis of the pre-existing 26 councils and not the 11 councils recommended by the RPA.

There is a strong path dependence in the new arrangements, as the United Kingdom moves from a system of administrative decentralization with limited scope for divergence but some room for learning, to political devolution, which allows for more divergence but might not necessarily favour exchange and learning. There is already some evidence of innovation and policy divergence, notably in the field of public service delivery. It is also true, however, that much policy appears to be rather similar, which may be a result of facing similar conditions, of coercion, or of policy transfer and learning. We therefore need to distinguish between concurrent policies, which may be similar because conditions are similar, policies that are borrowed merely from inertia or convenience and policies that are transferred. Among the latter we need to distinguish coercion, constrained adoption, and policy learning.

\section{Concurrent Policies}

Governments across the United Kingdom do face similar social and economic conditions and a range of standard policy tools, although the topography and demographic distribution in Scotland, Wales and Northern Ireland present some specific questions. The existence of a common market, common security area and welfare state poses limits on variation in the broad parameters of economic and social policy (Keating, 2002). There is also evidence that public opinion supports much the same policies (Jeffery, 2009). Yet this in itself does not always produce policy uniformity or work in the same direction. Opinion polls suggest that publics in both Scotland and England preferred the English (pre-2012) model of university finance but the Scottish model of care for the 
elderly, but this did not prevent divergence coming about. Even if the broad lines of policy are similar, moreover, experimentation and learning is possible in modes of delivery, detailed policies and combinations of instruments. Indeed, given the broad consensus on the welfare state that has prevailed in the UK since the late 1990s, it is precisely in these matters of delivery that innovation and divergence has been most marked. England has pressed ahead with New Public Management, competition, contracting-out, public-private provision and consumerism in public services, while Scotland and Wales (and, while devolution has been in operation, Northern Ireland), have, by and large, stuck to the traditional social democratic model of delivery (Keating, 2005; Donnelly and Osborne, 2005).

In many cases, policies may be borrowed simply by inertia, because of the weak policy capacity of the devolved government, so that the UK/English line becomes the default position. This may represent an extreme version of Walker's (1969) model of diffusion among US states, in which the larger and wealthier states with higher levels of policy capacity innovate and most others emulate. Analysis of legislation in the first (four year) term of the Scottish Parliament showed huge overlaps with English/UK legislation and often identical wording, except where there was a desire or need to differ in the details (Keating, Stevenson, Cairney and Taylor, 2003). In Spain and Italy, this is called the 'photocopy model' of policy-making. In Northern Ireland, it is the 'Shamrock photocopy', whereby NI civil service departments under Direct Rule adopted policies wholesale from Whitehall departments, changing only the title of the department on the document. Similarly, Welsh policy emulation is occasionally described disparagingly as 'dragonised' (in Scotland there may be reference to tartan photocopiers, although the source for such remarks may be London rather than Edinburgh).

\section{Coercive Transfers and Policy Constraints}

Directly coercive forms of policy transfer are not common in the United Kingdom since the two tiers are not mostly competing in the same sphere, as happens in other devolved or federal systems. Central government has also been wary of challenging devolved decisions, even when it seemed that it might have had constitutional grounds to do so. So it has accepted the decision of the Scottish Government to oppose the construction of nuclear power stations even though energy (apart from renewables) is a reserved responsibility (Cairney, 2011: 99).

Coercive transfer might also be expected from the political parties, especially the Labour Party when it dominated the UK, Scottish and Welsh governments. There was some pressure to adopt New Labour ideas about competition, contracting out and consumerism in public services, taken up by Jack McConnell as Scottish First Minister although explicitly rejected by Rhrodri Morgan in Wales. Unlike Morgan or even his predecessor Henry McLeish, McConnell took great care not to appear at odds with London. Wendy Alexander, in her brief stint as party leader in Scotland, also suggested a move in this direction. Massive pressure was brought to bear to try and persuade Scotland not to adopt free personal care for the elderly (McLeish, 2004). The Conservatives and Liberal Democrats, on the other hand, seem generally to have been more relaxed about divergence. The end of Labour dominance has seen a reduction in party pressures for convergence. There was no pressure at all for the devolved territories to adopt the controversial health service reorganization proposed by the Conservatives (with the reluctant aquiescence of the Liberal Democratics) for England after the 2010 General Election.

The situation is quite different in Northern Ireland, where British parties do not contest elections, accept membership applications or organise constituency associations (although the Conservatives did try an alliance with the Ulster Unionists in 2010 with a complete lack of success). Nonetheless, there was evidence of a New Labour effect in Northern Ireland, through two channels: the voluntary sector and Direct Rule ministers. Voluntary organisations in Northern Ireland have played an 
important role in formulating policy in areas such as health, education and housing, and lobbying ministers and civil servants. According to a one interviewee, NICVA (Northern Ireland Council for Voluntary Action) 'almost performs the role of the Labour Party' in NI, through its close relations with the party in London and its adoption of many of Labour's policy programmes. Labour Direct Rule ministers 2002-7 often introduced exact replicas of policies introduced in London, including waiting list targets, specialist schools (based on the English model of city academies), tuition fees, NICE guidelines, and 'public choice' reforms.

Coercive transfer might also be expected via financial instruments, given that the devolved territories are dependent almost entirely on transfers. ${ }^{\text {ii }}$ Yet in practice, fiscal dependence does not give the centre powers directly to coerce the territories into policy compliance since the Barnett formula transfers resources in a block, with no restrictions on their use. The main exception has been in capital finance, where the Treasury has been able to impose the use of the Private Finance Initiative (relabelled Public Private Partnerships under New Labour) for capital projects, since the devolved assemblies lack borrowing powers. ${ }^{\text {iii }}$ It has also imposed a division between capital and current spending on the devolved bodies. Similarly, the rules on public borrowing put pressure on local authorities to sell their housing stocks to housing associations, as a means of raising private sector capital to improve housing quality. The Treasury has also offered (outside the Barnett Formula) to pay off the debt on council housing if the tenants agree in a ballot to transfer to housing associations, something that was accepted in Glasgow but not in Edinburgh and other communities (Cairney, 2011: 215).

On the other hand, the total amount of expenditure is fixed so that if England were to move away from taxation and towards fees for funding public services the devolved territories would see the transfers reduced and have either to introduce fees themselves or seek to raise their own taxes. This imposes rather strict policy constraints on divergence in spending programmes. Nor does the Barnett formula allow the devolved territories to recoup moneys saved by the Treasury as a result of their own policy innovations. So Scotland lost its argument for getting back Attendance Allowances saved by free care for the elderly and was told that Council Tax Benefits could not be used to sustain the (now abandoned) Local Income Tax (Cairney, 2011: 53).

Financial pressures may be magnified by spill-over effects as the impact of spending decisions cannot be contained, or entitlements defined, territorially. Benefits available in one jurisdiction may be available to people from outside, or there may be migration. An example of these combined effects is provided by university 'top up' fees, introduced in England (to raise fees from over $£ 1000$ to over $£ 3000$ per year) by the Labour Government, and copied by Northern Ireland under Direct Rule, but rejected by cross-party consensus in the Scottish Parliament and later, in an attenuated form, in Wales. The later decision not to charge top-up fees but maintain university funding at similar levels to England involves considerable costs and a knock-on effect for other policy areas. The decision of the incoming SNP Government in 2007 to abolish the residual fee (the graduate endowment paid after finishing university) further widened the gap. This potentially gave English universities an advantage and, since the devolved administrations cannot effectively use taxes to replace fees, they had to find the lost resources from other programmes. There was a cross-border effect, as university students are mobile across the United Kingdom.

The effect was most pronounced in Wales as the jurisdiction most integrated with England and sharing the closest and most porous geographical and social border. Although the tuition fee regime was formally passed to the Welsh Assembly in 2004, its new power was undermined by crossborder pressures. The Rees review (Welsh Assembly Government, 2005) concluded that any significant departure from English policy would have profound consequences on student and staff movement across the border. Lower fees would mean too many English students studying in Welsh 
universities at the expense of domestic students, while lower investment could cause staff flows in the opposite direction (50 per cent of the Welsh staff live within 50 miles of the border). As a result, the Welsh Government defined the problem primarily as one of the English effect and recommended following the UK Government lead. However, the issue did not end there. The decision came at a time when AM Peter Law's absence from the National Assembly for Wales put the government in a minority and gave the opposition parties the chance to exert some power. This they did by focussing attention on a well-established frame in Welsh politics - policy distance from England combined with a desire to benefit the Welsh population. Therefore, indirect coercion played a huge part in the policymaking process but did not produce a predictable outcome. The resultant policy was a fudge, in favour of targeted additional grants (the tuition fee grant) to Welsh students studying in Wales, and departing from the previous policy focused more on the links between income (rather than territory) and HE access through a national bursary scheme open to all UK residents studying in Wales. In 2009 the link between maintenance and income was partly reestablished, moving towards a larger means-tested element, but only for Welsh domiciled students. The WAG removed the tuition fee grant of $£ 1980$ per year (i.e. the grant that covered the cost of top-up fees) for new students from 2010/11 but raised the means-tested Assembly Learning Grant (WAG, 2009).

In Scotland the spillover effect on policy was more muted, in part because the geographical boundaries are less porous (although there is a large number of English and Northern Irish students at Scottish universities), but the financial issue has not been resolved. As a result of coalition negotiations between the Labour and Liberal Democrat parties, a committee was established (the Cubie committee) and a compromise was reached that Scottish-domiciled students would not pay fees but those from elsewhere in the United Kingdom would (EU students are legally entitled to pay the same as Scottish students). Scottish students would instead pay a postponed 'graduate endowment', the proceeds of which would be used to fund bursaries for needy students. Further pressure came when the UK Government introduced higher 'top-up' fees and the SNP Government then moved in the opposite direction, abolishing even the graduate endowment for Scottish (and EU students) while other UK students would pay only the original non-topped up fee (which has gone up with inflation but is still only half the top-up level). When this threatened to provoke a flood of English students, the Scottish Executive took powers to charge non-Scottish medical students at a higher rate. Even this provoked some internal criticism that they were giving away an important Scottish principle.

There was also evidence of both direct and indirect coercion on the issue of tuition fees in Northern Ireland. The UK Government introduced up-front tuition fees and removed maintenance grants for local university students under Direct Rule in 1998. In a review of student finance in 2000, the Northern Ireland Assembly Committee for Further and Higher Education advocated the Scottish model, with the abolition of up-front tuition fees and reintroduction of grants for low-income students. This was rejected by the NI Minister for Higher Education as too expensive and possibly contravening equality measures, because offering free tuition to all would benefit the wealthy more than the disadvantaged (Tonge and Evans, 2002; Osborne, 2003). In a further review of higher education in 2006, Northern Ireland introduced a system of tuition fees identical to that of England, replacing up-front fees with variable fees and student loans, and introducing maintenance grants for low-income students. The introduction of top-up fees went against the wishes of all of Northern Ireland's political parties (BBC News, 8 April 2004). This had a spillover into the Republic of Ireland, with indications that Republic of Ireland students have been deterred from pursuing their studies in Northern Ireland, and a loss of students from the University of Ulster's Derry campus.

By 2010, however, financial pressures had forced governments in all four territories to reconsider the issue. For a time it appeared that the Scottish parties could discretely follow England while 
pretending not to by introducing a graduate tax which, depending on the details, might not differ much from a deferred fee, as practised in England. The decision by the UK Coalition Government to raise fees in England drastically (to a maximum of $£ 9000$ per year) and to rule out a graduate tax on both equity and technical grounds, provoked a new debate in Scotland and Wales - but party competition in the approach to the devolved elections of 2011 led Labour in both nations, together with the SNP and Plaid Cymru, to rule out fees. Later, the SNP Government announced that it would allow universities to raise fees for non-Scottish (and non-EU) students in Scotland up to maximum allowed in England itself. ${ }^{\text {iv }}$ The situation in Wales in more complicated. The Welsh Government announced in 2010 that Welsh Universities would allowed to charge up to $£ 9000$ per year for all UK students (if they met certain wider access criteria), but future 'Welsh domiciled' students studying in the UK would be grant funded to allow them to pay no more than the amount now paid by current Welsh students (£3290), while the Higher Education Funding Council For Wales announced in 2012 a plan to reserve a proportion of Welsh university places to institutions charging below $£ 7500$. Following the Scottish route, in Northern Ireland the Executive made a decision to freeze tuition fees for NI students attending universities in NI in 2011. The decision meant that tuition fees would remain at $£ 3,500$ per year for Northern Irish students, whilst students from the rest of the UK studying in NI would face costs of up to $£ 9,000$ per year.

Moves to abolish health service prescription charges in all three devolved territories also raised questions of financial viability and overspills. The National Assembly for Wales decided to phase them out from 2003-7, but faced initial problems related to cross-border spillovers (the potential for patients living in England to have their prescriptions filled in Wales). Northern Ireland phased them out from 2008-10. In Scotland, the SNP Government was committed to a similar model but, as the resources have to be found within existing budgets, decided instead to reduce them more progressively, finally abolishing in 2011. Cross-border spillovers here are more limited since it would not be worth people in England travelling all the way to Scotland to save such a small amount of money. The UK Government strongly resisted abolition or reduction in England, arguing that, like free personal care, it was 'unaffordable'.

Political spillovers are often more difficult to handle as citizens demand parity in services and charges and sectoral pressure groups try to compare spending levels on individual items to bolster their claims. It is technically difficult to compare public expenditure allocations and priorities among the various parts of the United Kingdom as (not entirely accidentally) the data are not available in similar forms, at similar levels of aggregation, across services. This makes it more difficult for interest groups to demand parity within individual fields but it does not stop them trying, aided by media reporting, such as the campaign of newspapers in the north of England systematically comparing public services in Northumberland and the adjacent Scottish Borders. Sometimes, when a high-profile announcement is made by the Chancellor of the Exchequer, allocating money for a sensitive or hard-pressed service, the pressure for the devolved administrations to apply the Barnett consequentials to the same service is overwhelming. For example, the Scottish Government immediately mirrored the promise by the UK Coalition Government in the UK to re-introduce Enterprise Zones, despite the criticisms made of the earlier, 1980s programme, that it merely redistributed activity. Earlier, the budget of 2002 increased spending for English health and promised further rises for five years ahead, as part of a long-term programme of investment. The Scottish Executive promptly agreed to spend the consequentials on health. Even here, however, there is some scope for choice as the Scottish Minister of Finance later added that this did not mean the money would necessarily go to the health department but could cover fresh fruit for school children or breakfast clubs for poor communities (Kerr, 2002). In 2008 the Labour Party in Scotland loudly condemned the SNP on the grounds that the percentage increase in health spending in Scotland was smaller than that in England, although this is largely the effect of the Barnett Formula (the SNP of course blamed Labour for that very reason). The press are 
much given to this type of comparison, as shown by an article in 2003 leading with the line 'measures taken by Westminster to reduce council taxes in England will not apply in Scotland, the Scottish Executive said yesterday' before conceding (several paragraphs later) that the situation was quite different since council tax rises in Scotland had been well below those in England (Ritchie, 2003). An article in 2004 reported that for every pound per kilometre spent on roads maintenance in Scotland, £1.59 was spent in England, with motoring organisations claiming that 'Scots have been short-changed' (Williams, 2004). In fact the comparison is almost meaningless, since Scotland has a huge network of lightly used rural roads in the Highlands; roads spending in Scotland fluctuates hugely from year to year depending on whether there is a big project under way; and most road spending is financed by local government. The Scottish Executive noted, moreover, that it had chosen to emphasise public transport, precisely the type of policy autonomy that devolution was supposed to achieve.

\section{Policy Competition}

There have been echoes in the UK debate of a fear of a race to the bottom (see Keating and Cairney's introduction to this volume). The Calman Commission (2008) feared that devolution might undermine shared UK social citizenship, implying (although not very coherently) that standards would be lowered if too much divergence is allowed. Trench (2008) reports fears that too much freedom for the devolved territories might undermine the 'gold standard' of the British university degree. If there is a race to the bottom, however, there is no reason to think that it is be the devolved territories leading it. On the contrary, the devolved UK governments have tended to adopt higher standards of welfare provision where they can and, if the gold standard of the university degree is being devalued anywhere, it is in England with its foundation degrees awarded by non-research institutions. In Scotland, the name of Higher National Diplomas has been kept for similar qualifications, which are distinguished from degrees, although they can be used as pathways into the university degree.

The limited evidence available on policy divergence, in fact, suggests that the devolved administrations have been engaged in a race to the top. This has put considerable pressure on the UK Government to equalize standards in England. Their response has been to try and insulate debate at the centre and to discredit innovations from the periphery. An enormous effort has gone into discrediting Scotland's 'free' personal care after UK ministers failed to persuade their Scottish Labour colleagues to drop the idea. When demographic pressures forced the UK Government to address the issue, the Scottish solution was quickly ruled out. Similarly, there were efforts to play down the significance of free prescriptions in Wales. In consequence, opportunities for policy learning have been lost.

There is a lack of shared indicators of policy performance across the United Kingdom (Andews and Martin, 2010) but, as the Whitehall departments are more given to summary indicators, which can be expressed in simple (if misleading) indicators, these are often given great prominence and used to assess the devolved territories, pressurizing them to follow English practice. One favoured indicator in the early 2000s was hospital waiting lists. In Wales, a decision had been taken to prioritize public health and prevention as against the English focus on waiting lists. This came under fire during the UK 2005 general election campaign when public and media attention focused on stark cross-border comparisons of performance statistics, made more significant by the flow of staff and patients between England and Wales. Jane Hutt was subsequently replaced by Brian Gibbons as Health Minister and the greater priority was given to waiting lists, a sign that the Welsh Government was willing to change tack and play 'catch-up' with England (Cairney, 2009a). However, although the Welsh government appeared to follow the English lead on waiting lists, this was in many ways presentational. In particular, Wales appeared to follow England's agenda on Patient Choice to tackling waiting times by furthering a 'second offer' scheme (in other words, if 
you wait too long then you have the chance to be treated elsewhere). Yet, the latter was devised before Gibbons was in office and, 'it is an equity, not choice, based system' (interview, Welsh Government special adviser, 2005). In England the individual drives the scheme on the assumption that $\mathrm{s} / \mathrm{he}$ is an informed, motivated, articulate consumer. In Wales the NHS identifies patients and negotiates an alternative time and location, with the cost and ability to travel built into the calculation. This suggests that the Welsh government merely drew inspiration from, or at most adapted, English policy rather than engaging in duplication.

In Scotland, it is more difficult to identify a direct effect. While there was also considerable attention to Scottish waiting lists and times in 2005, this was less pressing because there is a less porous boundary than in Wales and the Scottish Executive had more control over the presentation of success. For example, while, in September 2005, Tony Blair was publicly critical of the rejection of English NHS reforms in Scotland, the Scottish Executive's Permanent Secretary presented evidence suggesting that, 'outcomes in Scotland are, in many cases, as good as or better than in England' (Cairney, 2011: 179). Nicola Sturgeon, Health Secretary under the SNP administration, was less inhibited in specifically rejecting the English model, receiving support from the British Medical Association at its 2008 annual meeting, which happened to be in Edinburgh. At the same time, any decision to reject the English agenda is politically difficult and the Scottish Government is as committed as ever to measuring its success in performance management terms (Cairney, 2011: 183). Therefore, in this case the role of indirect coercive transfer is more subtle, promoting inertia rather than change. It contributes to the established paradigm (the 'medical model') and further undermines the ability of Scottish actors to shift the agenda and significant resources to wider determinants of health. The need to reduce waiting, so central to policy in England, is a powerful idea, and one which is extremely difficult to challenge.

In Northern Ireland, there was evidence of a direct effect from English NHS models and targetry. In June 2005, the Government (under Direct Rule) developed an approach to waiting lists based on the Greater Manchester model, following the recommendations of the Appleby Report and without public consultation. This included rigorous performance management, a separation of commissioning and providing to produce tensions, and clear targets so that no patient would have to wait more than 9 months for an outpatient appointment. In order to achieve these goals, experts from the Greater Manchester Alliance were brought to NI to overview the new processes and people were seconded from other health trusts in England. From the perspective of the civil service, these reforms could not have been achieved under devolution. When devolution re-commenced in 2007, a public consultation was undertaken to collect views on reforming health and social care. The Minister for Health sought to 'abandon Direct Rule proposals for future reform and develop structures that would better meet the needs of our local population' (McGimpsey 2009). Yet despite the rhetoric, the devolved ministry sought to continue Direct Rule policies with regard to waiting lists, PFI for new hospitals and performance targets, demonstrating the profound legacy that direct imposition has when there is insufficient drive to change policy under devolution (see also Greer, 2004 for a discussion of inertia in NI health policy overall). However, while Executive targets stated that patients should wait no longer than 21 weeks for an appointment, the BMA revealed in 2012 that NI had the worst waiting times for hospital appointments in the UK, with patients waiting up to a year to see a doctor. BMA Chair Laurence Buckman argued that "The difference between the waits here and the rest of the UK needs to be brought on to the public agenda... Nothing has changed, but in fact it seems to be worse than ever" (Belfast Telegraph, 27 March 2012).

Interested parties have also played with indicators to try and gain policy leverage. In 2010 the Nuffield Trust (Connolly et al., 2010) ${ }^{\mathrm{v}}$ produced a report comparing outcomes in health across the United Kingdom purporting to show that the English system was superior. The indicators were based on English practice and even then the detailed figures did not support the headline finding 
that England came out on top across the board. In this case, there was a counter-analysis from a Scottish research body (CPPR, 2010), giving a much more balanced picture, but this is a rather rare event.

\section{Policy Communities}

UK-wide policy communities and professional networks are potentially important factors for convergence and transfer, representing 'epistemic communities' with shared ideas about problems, solutions and instruments (Haas, 1992). Given the predominance of England, this can be a mechanism for centre-periphery transfer. The devolved territories lack the established and wellresourced think tanks that have been so influential in London in recent decades and those that they have tend to take ideas from outside rather than coming up with initiatives of their own. It is also striking that they lean heavily towards the New Public Management (NPM) and market liberalism that is dominant in England but much less entrenched in the other parts of the United Kingdom. Their influence in exporting the NPM is limited but nor have the territories made any impact in England with their own models, which tend to be less well articulated or marketed.

It is easier to resist pressures to conform to the Whitehall line where there are established policy communities in the devolved territories. This varies considerably by territory and by sector (Keating, Cairney and Hepburn, 2008). Compulsory education has always been organized differently, particularly in Scotland, which has its own qualifications and indicators, and Northern Ireland, where education continues to be academically selective and religiously segregated. Wales is more tied to English policy but has traditionally demonstrated a higher commitment to comprehensive schools and a stronger role for local education authorities. The UK agenda on performance management through pupil testing is less persuasive and subject to greater professional opposition than in health, while the flow of school staff and students between England and Wales is not as significant the equivalents in health or higher education. Therefore, Scotland and Wales have been able to distance themselves from league tables and there is less emphasis on testing. In Scotland, these differences in testing were already apparent and then accelerated following devolution, while in Wales the decision to abolish testing at key stages was a much higher profile instance of divergence from England. Wales followed Scotland in developing a close-knit policy community with strong professional values that reduce receptivity to external ideas. Increased attention to problems with the administration of tests raises the prospect of policy change in England, which began in 2008 with planned abolition of testing for 14-year olds, but there is not much evidence that this was inspired by learning from Scotland or Wales as opposed to policy failures within England (and recent experience suggests that testing, as part of curriculum reform, has returned to the top of the Education Secretary's agenda). In Northern Ireland, school league tables were introduced under Direct Rule in 1993, but abolished by Education Minister Martin McGuinness in 2002 in order to bring the region into line with the Republic of Ireland. However, other education decisions taken by DR ministers were carried forward by McGuinness after devolution, including the introduction of a Pre-School Expansion Programme and, most controversially, a commitment to abolishing ' $11+$ ' academic selection in 2002 . This was eventually introduced on an area basis in 2006, but continues to be bitterly opposed by non-complying grammar schools (Belfast Telegraph, 2 April 2010). If successful, the abolition of private transfer tests is likely to bring the region more in line with compulsory education in Scotland and Wales.

In Scotland, the disproportionate presence of medical schools and the existence of medical royal colleges has provided support for distinct policies and departures from the Whitehall line. Private medical providers, a powerful lobby in Whitehall, have little political presence in Scotland, perhaps because the market is too small or because they think that the political climate is more hostile. Lobbying for privatization and marketization of public services has been left to small but vocal think tanks. 
Scottish mental health legislation also shows the importance of distinct policy communities. The potential effect of externalities was high following considerable Scottish attention to the UK media and the UK government response to high profile murders by mentally ill patients (such as Michael Stone) who proved difficult to treat. There was also some early evidence that Scotland was caught up in this approach to mental health, since the first Act passed by the Scottish Parliament was used to close a legal loophole regarding the treatability of patients with personality disorder, following a legal case in which Noel Ruddle successfully applied for his release from hospital when deemed untreatable. Yet, from 1999 the Scottish and UK governments took radically different paths. Scotland adopted a consensual consultation process based on a balance between coercion and the need for patient rights, encapsulated in the idea of reciprocity, in which patients detained against their will would have a right to the best treatment. England meanwhile was bogged down by a 10 year struggle based on interest group opposition to the government's attempts to detain patients before they had committed any crimes (by creating a new condition DSPD, or dangerous people with severe personality disorder) without giving the same assurances on rights (Cairney, 2009b). Three factors distinguish this case from that of waiting times. The first is that, while mental healthrelated crime is often high profile, public and government attention to this area is much more fleeting and there is less pressure to act. Second, we are less able to compare the effects of diverging policies (the only mental health indicator in vogue relates to the rate of suicide), particularly since Scotland has always had separate mental health legislation. Third, a range of factors suggest that in this case the receptivity to transfer would be low and Scottish ministers would be impervious to coercion. This includes the 'devolution effect', in which Scottish ministers were keen to make their mark and create consensus within Scotland but also specific policy conditions such as the lower rate of mental health closure (meaning fewer high profile media coverage of mentally ill and dangerous people wandering the streets) and historical psychiatric opposition in Scotland to treating personality disorder, meaning that capacity to detain people was less likely.

A reverse example is provided in Scottish penal policy, where a tradition of welfarism had survived in the pre-devolution years thanks to the existence of a liberal policy community, in contrast to developments in England since the early 1990s (McAra, 2007). After 1999 there was a great deal of cutting and pasting under the Labour-Liberal Democrat coalition (1999-2007) but, at least while the Liberal Democrats held the Justice portfolio, a less populist and authoritarian line than in England. This changed after 2003, when Labour claimed the brief for itself and launched what was tagged the 'war on neds' (a derogatory term meaning hooligans or petty criminals). First Minister Jack McConnell visited Manchester, the ASBO (anti-social behaviour order) capital of the UK and commended its practice. The scope of ASBOs was extended and a series of tough law and order laws brought in. McAra (2007) suggests, interestingly, that this was not the result of pressure from London for conformity but rather a populist ploy by the Labour Party in Scotland following devolution. In this case, the alignment of public opinion on both sides of the border was the key factor, together with the eagerness for Scottish politicians to reconnect with their bases.

Policy communities and interest groups can occasionally take up ideas from the devolved administrations and feed them back to the centre but with mixed results. Indeed, without being exported, policy innovations can prove fragile in competition with those from larger places. The British Medical Association's commendation of the Scottish model of health care seems to have had no influence in London, since it concerned such a central matter of government policy. The Scottish approach to mental health has also been supported by interest groups throughout the UK.

So the periphery is penetrated by influences from the centre, but England seems to be largely isolated from Celtic social democracy (Keating, 2007). On the other hand, being supported by 
groups outside their own territory can help devolved governments defend their own position, as is shown in the area of NHS reform and mental health.

\section{Implementation}

Formal transfer or imitation of a policy does not, of course, mean that it will work in the same way in different jurisdictions. While most of the policies of Conservative governments in the 1980s and 1990s were applied in Scotland, Wales and Northern Ireland (Midwinter, Keating and Mitchell, 1991) they were not always followed through where a societal response was required. So the internal market in health did not really work in the devolved territories, given the population distribution and lack of enthusiasm on the part of the medical profession. The provision for schools to opt out of local authority control was a virtual dead letter in Scotland and used minimally in Wales despite its relative integration with English education. The same scope for divergence masked by broad uniformity may be true after devolution. ${ }^{\mathrm{vi}}$ Many fewer ASBOs continued to be issued in Scotland than in England, suggesting that the practical effect of the policy transfer was limited (McGarvey and Cairney, 2008; Cairney, 2011: 196).

Conversely, when governments have consciously sought to differentiate their policies, there have been pressures for re-convergence in practice. The flagship policy on free personal care for the elderly in practice comes down to detailed rules on who is eligible for what and under what conditions and here there is less difference in practice. The same could have happened with student finance, as the difference between deferred fees, graduate contributions and a graduate tax is blurred although this was not to be. The difference in prescription charges is also blurred by various exemptions that cover almost 90 per cent of prescriptions in England.

\section{Policy Learning}

All of the developments described thus far represent policy transfer in a more or less coercive and constraining way. The term policy learning, on the other hand, should properly be confined to voluntary adoption and adaptation of ideas from elsewhere. The direction of such policy learning can be from the centre to the periphery, from periphery to centre, around the periphery and internationally. In the United Kingdom, the first has predominated. This is partly because of the asymmetry, with Whitehall departments being larger and with a bigger policy capacity than their counterparts elsewhere. In one sense, we can say that the devolved system has no centre, since there are no departments with a UK or British brief except in reserved matters and intergovernmental policy-making machinery is weakly developed. In another sense, however, there is a centre and it is England, which sets the policy agenda and initiates most big policy changes. Further, the literature (Cairney, 2008a; 2011; Keating, 2005a; 2010; McGarvey and Cairney, 2008) and interview evidence $^{\text {vii }}$ suggests that the devolution of UK interest groups has not kept pace with political devolution, while the ability of local government to engage at that level diminished for some time following reorganisation. In contrast, the UK government has a relatively high policy capacity and a well-established set of policy networks including interest groups and a range of think tanks not present elsewhere. Therefore, England (as represented by the UK government) has become the larger, 'wealthier' region with the biggest staff and arguably a population more tolerant of change, or at least subject, as the largest and least homogeneous area, to the biggest problems of planning. It is also the jurisdiction most likely to advertise its success and seek uniformity through a shared party of government, interest groups, think tanks or the civil service, and to initiate policy change with knock-on effects for other jurisdictions. The devolved territories, given their limited capacity, are the most likely to respond by emulating the UK government lead or, as in the case of Welsh homelessness, effectively relying on UK government staff. The predominance of England also stems from the fact that the UK government has taken care to try and insulate the centre from peripheral pressures and contain the race to the top. 
Under Gordon Brown (UK Chancellor from 1997-2007), the Treasury became an important source of innovation, developing into a highly interventionist agency covering the whole of domestic policy. Public Service Agreements with targets were imposed upon the Whitehall Departments but did not, for constitutional reasons, extend to the devolved administrations. Many of its experimental initiatives did extend across the United Kingdom and intertwined with devolved responsibilities, although Adams and Robinson (2002) exaggerated in describing it as a new UK policy centre. The 'New Deal' jobs programme provided additional money and overlapped with devolved responsibilities in education and training, as did the welfare to work programme. While the policy is in principle locally based, with possibilities for variation and experimentation, the Treasury did not take what might seem the obvious step and set up a devolved one for Scotland, Wales and Northern Ireland.

Learning from the periphery by the centre is less common. The most high profile has been tobacco policy in which England followed (to some extent) the rest of the UK and Ireland to introduce a comprehensive smoking ban in public places (Cairney, 2007). NICE adopted the single technology assessment developed by the Scottish Medicines Consortium, whose recommendations are often followed by English Primary Care Trusts. Scotland has also led the way on mental incapacity legislation, with evidence of: close contact between Scotland's Office of the Public Guardian and the Department for Constitutional Affairs when the latter was drafting its bill; health department links while the UK redrafted its mental health act; and English interest in Scottish pilots on psychological therapies (Cairney, 2011: 188-90). The SNP Government's decision to introduce minimum alcohol pricing in 2009 was also being considered by the UK Department of Health only a few weeks later and the House of Commons Health Committee (2010), investigating the issue in England, took a great deal of interest in the Scottish debate, as well as Scottish licensing practice. The UK Labour Government rejected the idea, under heavy pressure from the drinks industry, and Scottish Labour followed suit, but the Scottish debate did feature in the English agenda. The new coalition government in 2010, under pressure from medical and public health lobbies, appeared to take a less hostile line and even Scottish Labour was shifting its position, accepting that something might be done on a UK-wide basis. Scottish practice on holding DNA of people arrested but not charged or convicted was also used in the debate in England and Wales and the UK coalition government has now committed itself to the Scottish model.

The Scottish system for deferring university fees influenced the English model, although the policy still diverges radically. There are also some examples of learning through professional networks. For example, schools inspections agencies often share best practice based on a strong professional ethos, while Scotland's guarantee of a year's employment for probationary teachers gained currency in the rest of the UK.

There are fewer channels and opportunities for periphery-periphery transfer, although the governments in place since 2007 have stronger political motives for encouraging this and there are moves to strengthen links. An early example of periphery-periphery transfer was the idea of a Children's Commissioner, which originated in the National Assembly for Wales in 2001, before moving to Northern Ireland (2003), Scotland (2004), and then England (2005). More recently, the Northern Ireland Executive announced the establishment of an Older People's Commissioner in 2007, a position that was created in Wales in 2006 and attracted debate in Scotland (before being rejected following Scottish Parliament concerns over the costs of commissioners). Scotland and Northern Ireland also followed Wales' lead on prescription charges.

A certain amount of learning occurs through European networks. The Structural Funds, due to additionality rules, do not bring any more money into the territories than they would get anyway under the Barnett Formula, but do require them to spend the money in a specific way. European 
models of partnership and networking have penetrated local development mechanisms, where they have adapted in various ways. While the US remains a key source of learning for the UK, Wales's focus on preventative health has led it to study innovation in Finland while the new Scottish Government's focus on alcohol has led it to New Zealand. Scotland, Wales and Northern Ireland have all studied the Nordic countries when developing policies on early years education, with NI introducing a pilot scheme based on Scandinavian and NZ models that deliberately delays formal teaching to focus on childrens' social skills. Furthermore, all three devolved governments are influenced, to a varying extent, by developments in Ireland. This is especially true for Northern Ireland, whose policy learning from, and cross-border activities with, the Republic of Ireland stem from the 'Strand Two' clause in the Good Friday Agreement which encourages deepening allIreland programmes and relationships. The post-2007 Scottish Government's agenda on independence has also led to increased interest in the 'arc of prosperity nations', including Ireland, Norway and Iceland, or at least those who can demonstrate the link between autonomy and innovation.

\section{Conclusion}

Policy transfer under UK devolution has thus been rather sporadic. There is a certain amount of coercive policy transfer, mainly by funding mechanisms although these are not systematic. Studies of devolution largely concur that, rather than representing a more powerful, interfering neighbour, the UK government has largely disengaged from devolution. Representatives of devolved governments and groups are more likely to criticise a lack of UK awareness of devolution - and the effects of their policies on devolved governments - than highlight examples of overt interference. On the other hand, the similarity of problems, policy communities and parallel trends in public opinion have ensured that policy does not differ radically, rather producing concurrent policies. Overspills have constrained divergence and led to some quasi-coercive policy transfer, more so in Wales where the border is more porous and there is generally more interdependence. The situation in Northern Ireland has been different, due to the stop-start nature of devolution since 1998. Under Direct Rule arrangements, policy-making clearly followed the English model in an effort to achieve inter-institutional parity. However, there is indication that the devolved institutions have sought to break this pattern, looking to Scotland, Wales and Europe to draw policy lessons, especially on public health, higher education and children's issues. Political overspills, with governments obliged to match service improvements over the border, have been contained as Whitehall has sought to crush politically embarrassing differences, as in the high-profile and sustained campaign against free personal care in Scotland. Otherwise it has sought to limit the contagion by ignoring what is happening elsewhere so that politics and policy debates in the four jurisdictions are increasingly self-contained. Overall, the nature of policy problems is defined by domestic actors. The relevance of ideas from England to the rest of the UK is increasingly weak and devolved governments are more immune from pressure, especially after 2007. The Joint Ministerial Committee system, which might have provided a venue for policy learning, was allowed to atrophy. It has now been reintroduced as a mechanism of intergovernmental dialogue, but whether it will develop into a policy forum is uncertain. There is so far a singular lack of policy learning or lesson-drawing in the form of serious efforts to learn about which policies are most effective and why. Devolution is not yet the UK's laboratory of democracy.

\section{References}

Adams, John and Peter Robinson (2002), 'Divergence and the Centre', in John Adams and Peter Robinson (eds), Devolution in Practice. Public Policy Differences within the UK, London: Institute for Public Policy Research.

Andrews Rhys and Steve Martin (2010), 'Regional Variations in Public Service Outcomes: The Impact of Policy Divergence in England, Scotland and Wales, Regional Studies, 44.2: 1-16. 
Bennett, C. (1991) "What is Policy Convergence and What Causes It?", British Journal of Political Science, 21, 2, 215-33

Birrell, D. (2008) 'The Final Outcomes of the Review of Public Administration in Northern Ireland. Tensions and Compatibility with Devolution, Parity and Modernization', Public Administration, 86, 3, 779-93.

Birrell, D. (2010) 'Public sector reform in Northern Ireland: policy copying or a distinctive model of public sector modernization?', Public Money \& Management, 30, 2, 109-16.

Cairney, P. (2007) 'A 'Multiple Lenses' Approach to Policy Change: the Case of Tobacco Policy in the UK', British Politics, 2, 1, 45-68

Cairney, P. (2008a) 'Has Devolution Changed the British Policy Style?, British Politics, 3, 3, 35072

Cairney, P. (2009a) 'Implementation and the Governance Problem: A Pressure Participant Perspective', Public Policy and Administration, 24, 4, 355-77

Cairney, P. (2009b) 'The 'British Policy Style' and Mental Health: Beyond the Headlines", Journal of Social Policy, 38, 4, 1-18

Cairney, P. (2011) The Scottish Political System Since Devolution (Exeter: Imprint Academic)

Cairney, Paul and Michael Keating (2004), 'Sewel Motions in the Scottish Parliament', Scottish Affairs, 47, Spring (2004): 115-34.

Calman Commission (Commission on Scottish Devolution) (2008), The Future of Scottish Devolution within the Union: A First Report, presented to the Presiding Officer of the Scottish Parliament and to the Secretary of State for Scotland, on behalf of Her Majesty's Government.

Devolution (Edinburgh: Edinburgh University Press)

Carmichael, P. (2002) 'The Northern Ireland Civil service: Characteristics and Trends since 1970', Public Administration, 80:1.

Carmichael, P. and R. Osborne (2003) 'The Northern Ireland Civil Service under Direct Rule and Devolution', International Review of Administrative Sciences, 69:2.

Centre for Public Policy for Regions (2010), Spending on Health. Scottish Government Budget Options Briefing Series, no. 3, Glasgow: CPPR.

Connolly Sheelah, Gwyn Bevan and Nicholas Mays (2010), Funding and performance of healthcare systems in the four countries of the UK before and after devolution, London: The Nuffield Trust.

Davidson, L. (15.3.2009) 'SNP accused of being soft on crime as it ends ASBOs for under-16s' The Times http://www.timesonline.co.uk/tol/news/uk/scotland/article5914622.ece

Dolowitz, D. and Marsh, D. (1996) "Who Learns What from Whom: a Review of the Policy Transfer Literature", Political Studies, XLIV, 343-57

Dolowitz, D. and Marsh, D (2000) "Learning from Abroad: The Role of Policy Transfer in Contemporary Policy-Making", Governance, 13, 1, 5-24

Donnelly, C. and R. Osborne (2005) 'Devolution, Social Policy and Education: Some Observations from Northern Ireland', Social Policy \& Society, 4:2.

Greer, S. (2004) Territorial Politics and Health Policy: UK Health Policy in Comparative Perspective (Manchester: Manchester University Press).

Haas, P.M. (1992) 'Introduction: Epistemic Communities and International Policy Coordination', International Organization, 46, 1, 1-35

Hayes, M. (1995) Minority Verdict, Belfast: Blackstaff Press.

Hoberg, G. (1991) 'Sleeping with an Elephant: The American Influence on Canadian Environmental Regulation' Journal of Public Policy, 11, 1, 107-131

Hoberg, G. (2001) “Globalization and Policy Convergence: Symposium Overview”, Journal of Comparative Policy Analysis: Research and Practice, 3, 127-32

Holzinger, K. and Knill, C. (2005) 'Causes and conditions of cross-national policy convergence', Journal of European Public Policy, 12, 5, 775-796.

House of Commons Health Committee (2010), First Report. Alcohol, 8 January. 
Hooghe, L. and G. Marks (2003) 'Unravelling the Central State, but How? Types of

Multi-level Governance', American Political Science Review, 97, 2, 233-43

Jeffery, Charlie (2009). 'Devolution, public attitudes and social citizenship', in Scott Greer (ed.), Devolution and Social Citizenship in the UK, Bristol: Polity.

Keating Michael, Linda Stevenson, Paul Cairney and Katherine Taylor (2003): 'Does Devolution Make a Difference? Legislative Output and Policy Divergence in Scotland', Journal of Legislative Studies, 9.3 110-39.

Keating Michael, Paul Cairney and Eve Hepburn (2008):, 'Territorial Policy Communities and Devolution in the United Kingdom', Cambridge Journal of Regions, Economy and Society doi:10.1093/cjres/rsn024 1-16.

Keating, Michael (2005; 2010), The Government of Scotland. Public Policy-Making after Devolution, first and second editions, Edinburgh: Edinburgh University Press.

Keating, M. (2005b) 'Higher education in Scotland and England after devolution', Regional and Federal Studies, 15, 4, 423-35

Keating, Michael (2002), 'Devolution and Public Policy in the United Kingdom: convergence or divergence?', in John Adams and Peter Robinson (eds), Devolution in Practice. Public Policy Differences within the UK, London: Institute for Public Policy Research, 2002,.

Keating, Michael (ed.) (2007), Scottish Social Democracy, Brussels: PIE/Peter Lang.

Keating, Michael and Paul Cairney (2006), 'A New Elite? Politicians and Civil Servants in Scotland after Devolution', Parliamentary Affairs, 59.1: 1-17.

Kerr, Andy (2002), oral evidence to Scottish Parliament Finance Committee, 23 May 2002.

Maxwell, 2008).

Lipsett, A. (5.12.2008) 'Devolution 'creates university funding gap' The Guardian http://www.guardian.co.uk/education/2008/dec/05/devolved-universities-funding

McAra, Lesley (2007), 'Welfarism in Crisis: Crime Control and Penal Practice in Post-Devolution Scotland, in Michael Keating,(ed.), Scottish Social Democracy, Brussels: PIE/Peter Lang.

McGarvey, N. and Cairney, P. (2008) Scottish Politics (Basingstoke: Palgrave)

McGimpsey, M. (2009) 'The Health and Social Care Reform Bill completes its Assembly process' Belfast: NI Executive Press Release, 12 January 2009.

McLeish, Henry (2004), Scotland First. Truth and Consequences, Edinburgh: Mainstream.

Midwinter, Arthur, Michael Keating and James Mitchell (1991), Politics and Public Policy in Scotland, Basingstoke: Macmillan.

O'Leary, B. (1988) 'The Nature of the Agreement', Jon Whyte Memorial Lecture, Queen's University Belfast.

Osborne, R. (2003) 'Higher Education in Further Education: Northern Ireland', Higher Education Quarterly, 57:4.

Ritchie, Murray (2003), The Herald, 18 December.

Rose, R. (1993) Lesson-Drawing in Public Policy (New Jersey: Chatham House)

Shipan, C.R. and Volden, C. (2008) 'The Mechanisms of Policy Diffusion', American Journal of Political Science, 52, 4, 840-857

Tonge, J. and J. Evans (2002) 'Party Members abd the Good Friday Agreement in Northern Ireland', Irish Political Studies, 17:2.

Trench, Alan (2008), Devolution and higher education: impact and future trends, Universities UK. Walker, J.L. (1969) "The Diffusion of Innovations among the American States", American Political Science Review, 63, 880-99

Welsh Assembly Government (2008) Review of Higher Education in Wales Phase 1: Student Finance Arrangements http://new.wales.gov.uk/topics/educationandskills/policy_strategy_and_planning/feandhe/wagrevie ws/reviewhighereducationwales/?lang=en

Welsh Assembly Government (2009) The making of the Assembly Learning Grants and Loans $\begin{array}{llll}\text { (Higher } & \text { Education) } & \text { (Wales) } & \text { Regulations }\end{array}$ 
http://wales.gov.uk/publications/accessinfo/drnewhomepage/educationdrs2/educationdrs2009/learni nggrant09/?lang=en

Williams, Martin (2004), Herald, 20 February.

\footnotetext{
${ }^{\mathrm{i}}$ This provides for Legislative Consent Motions whereby the Scottish Parliament may ask Westminster to legislate in devolved matters. They mainly involve technical matters (Cairney and Keating, 2004).

ii The Scottish Parliament has the power to raise or lower the standard rate of personal income tax by three pence in the pound but technical and political constraints make this power effectively unusable.

${ }_{\text {iii }}$ Although the current Scotland Bill includes some provision for the Scottish Government to borrow to fund capital projects.

${ }^{\text {iv }}$ This meant that some Scottish universities have become more expensive for these students than most courses in England, since they charge the $£ 9000$ per annum for four, rather than three years.

${ }^{v}$ Although this is an independent research organization it is funded by the Nuffield group of private hospitals, which would stand to gain from an extension of the English model of private provision

${ }^{\text {vi }}$ An interesting recent example - on medical 'topups' - saw the SNP Government keen to downplay the role of private funding in a public healthcare system as exceptional (Cairney, 2011: 185).

vii Our project now draws on over 300 interviews conducted between 1999-2008. Two rounds of interviews in Scotland were supported by the ESRC's Devolution and Constitutional Change Programme, grant held by Professor Michael Keating (Keating, 2005). Interviews in Wales in 2005 and England in 2006 were supported by the University of Aberdeen (Cairney). Research in Northern Ireland and further research in England was supported by a Nuffield Small Grant (Cairney and Keating - see Keating et al, 2008).
} 